\title{
PEMANFAATAN SENI KARTOGRAFI UNTUK MENINGKATKAN KEMAMPUAN SPASIAL SISWA SMA NEGERI 1 PEMULUTAN
}

\author{
Siti Asiyah $^{1 *}$, Mega Kusuma Putri ${ }^{1}$, Eni Heldayani ${ }^{1}$, Maharani Oktavia ${ }^{1}$, Eva Dina \\ Chairunisa $^{2}$, Kiki Aryaningrum ${ }^{1}$
}

\author{
${ }^{1}$ Program Studi Pendidikan Geografi, Universitas PGRI Palembang, Palembang, Indonesia \\ ${ }^{2}$ Program Studi Pendidikan Sejarah, Universitas PGRI Palembang, Palembang, Indonesia \\ *Penulis korespodensi: asiyahgeoadventure@gmail.com
}

\begin{abstract}
Abstrak
Pengabdian Kepada Masyarakat ini dilatarbelakangi oleh kondisi kurangnya kemampuan spasial siswa. Kartografi merupakan seni teknik dan proses dalam pembuatan peta. Peta merupakan representasi atau gambaran unsur-unsur atau kenampakan abstrak yang ada kaitannya dengan permukaan bumi. Dalam pemanfaatannya, seni kartografi dapat membantu siswa dalam hal pemahaman spasial (ruang). Kegiatan pengabdian ini bertujuan untuk melatih keterampilan siswa dalam menggambar berbagai kenampakan atau fenomena atau simbol (dapat berupa titik, garis dan area), melatih ketelitian menggambar peta, dan menambah pendalaman materi pembuatan peta. Kegiatan pengabdian ini dilaksanakan dengan metode pembelajaran praktikum terbimbing. Praktikum ini dilaksanakan dalam waktu sehari dan diikuti oleh 40 siswa. Hasil pengabdian ini menunjukkan respon positif, hal ini ini bisa dilihat dari antusiasme para siswa serta testimoni yang diberikan oleh siswa.
\end{abstract}

Kata Kunci: Kemampuan Spasial; Seni Kartografi.

\begin{abstract}
This community service is motivated by the lack of students' spatial ability. Cartography is an engineering art and a process in making maps. Maps are representations or depictions of abstract elements or features that are related to the surface of the earth. In its use, the art of cartography can help students in terms of spatial understanding (space). This dedication activity aims to train students' skills in drawing various appearances or phenomena or symbols (can be in the form of points, lines and areas), train the accuracy of drawing maps, and increase the depth of map making material. This service activity is carried out using guided practicum learning methods. This practicum was held in one day and attended by 40 students. The results of this service show a positive response, this can be seen from the enthusiasm of the students and the testimonies given by students.
\end{abstract}

Keywords: Cartography; Spatial Ability.

\section{PENDAHULUAN}

Di era perkembangan jaman sekarang ini, kita dituntut mengikuti perkembangan jaman. Semakin tahun teknologi semakin berkembang dengan pesatnya, hingga merambah ke dunia pendidikan. Pemilihan media pembelajaran yang sesuai dapat memberikan peluang keberhasilan dalam mencapai tujuan pembelajaran. Seiring kebutuhan akan metode pembelajaran yang lebih efektif dan efisien, pemanfaatan media pembelajaran untuk pendidikan harus terus dikembangkan.

Pada proses pembelajaran, keberhasilan pembelajaran diukur berdasarkan ketercapaian kompetensi yang ditetapkan sejak awal kegiatan pembelajaran. Dengan demikikian semua pihak yang berpartisipasi aktif dalam proses pembelajaran peserta didik dan guru telah mengetahui arah pembelajaran. Kedua belah pihak perlu kerja sama, saling mendukung sehingga memungkinkan ketercapaian kompetensi yang ditetapkan secara meyakinkan dan untuk melaksanakan kegiatan belajar mengajar diperlukan langkah-langkah agar tujuan yang ditetapkan dapat dicapai. Hal yang harus dilakukan adalah menggunakan strategi belajar mengajar yang cocok dan sesuai dengan materi pokok disampaikan. Selain itu guru sebagai jantung proses pembelajaran harus disiapkan supaya memiliki kemampuan dan kreatifitas mengembangkan konten media pembelajaran yang menarik.

Kemampuan spasial merupakan salah satu cara berpikir terpenting bagi siswa untuk berkembang ketika mereka belajar ilmu geografi, ilmu bumi dan lingkungan. Kemampuan spasial melibatkan mengetahui dan memahami konsep dan hubungan spasial, bagaimana mewakili konsep dan hubungan tersebut dengan cara yang berbeda, dan juga bagaimana dapat bernalar dengan informasi spasial. Menurut lohman (1993) 
Kemampuan spasial didefinisikan sebagai kemampuan untuk membangkitkan, mempertahankan, mendapat kembali dan mengubah bayangan visual (Imamuddin dan Isnaniah, 2018). Di era global dengan tuntutan teknologi seorang siswa yang memiliki keterampilan spasial yang kuat adalah nilai plus dan keuntungan sendiri dalam kehidupan di masyarakat (Mohan, 2013).

Bidang Study Geografi memiliki peranan yang sangat penting bagi kehidupan. Salah satu peran penting yang saat ini banyak memperoleh perhatian dalam geosains adalah pengembangan spatial thinking atau berpikir spasial. Spatial thinking skills atau kemampuan berpikir spasial adalah salah satu aktivitas dalam proses pembelajaran geografi. Kemampuan berpikir spasial dapat membantu seseorang dalam menganalisis gejala geosfer yang terjadi dilingkungan sekitar. Bahkan dengan keterampilan spasial, seseorang dapat mengantisipasi hal-hal yang akan terjadi, seperti bencana alam, penentuan lokasi yang ideal untuk bermukim, dan lain-lain.

Menurut ICA (1973) Kartografi adalah seni, ilmu pengetahuan dan teknologi tentang pembuatan petapeta, sekaligus mencakup studinya sebagai dokumendokumen ilmiah dan hasil karya seni (Setyawati, 2013). Kartografi merupakan seni yang dikembangkan untuk membuat representasi permukaan bumi ke bidang datar. Namun, dalam perkembangannya Kartografi sangat diandalkan dalam membantu kegiatan pembelajaran yang terkait dengan aspek spasial. Geografi merupakan mata pelajaran yang fokusnya pada pengembangan berpikir spasial, sehingga kartografi menjadi sistem pendukung yang sangat diandalkan. Pemanfaatan kartografi dalam mengembangkan berpikir spasial tersebut telah diuji kehandalannya dalam sejumlah penelitian yang menunjukkan adanya kontribusi positif kartografi dalam mengembangkan kemampuan berpikir spasial (Setiawan, 2016). Objek kartografi adalah pembuatan peta sebagai refleksi dunia atau alam nyata (real world) yang setepat mungkin (Handoyo, 2009).

Kartografi memperhatikan aspek estetika peta, sehingga peta yang dihasilkan menjadi mudah dipahami terutama ketika disajikan dalam format cetak (hardcopy) (Susetyo dkk. 2014). Pada Pengabdian Masyarakat yang akan dilaksanakan oleh dosen Pendidikan Geografi Universitas Palembang ini adalah menjelaskan pengertian kartografi, pemanfaatan kartografi dalam kehidupan sehari-hari siswa SMA Negeri 1 Pemulutan dan memberikan praktikum kartografi.

\section{BAHAN DAN METODE}

Bahan yang digunakan dalam pengabdian ini adalah kertas kalkir, pensil, penggaris, penghapus, dan peta dasar. Pelaksanaan Pengabdian Kepada Masyarakat (PKM) di SMA Negeri 1 Pemulutan menggunakan pendekatan partisipatif melalui metode praktikum terbimbing. Pendekatan partisipatif dan praktik terbimbing diharapkan dapat memotivasi siswa untuk bersama-sama pendamping memecahkan permasalahan siswa terkait rendahnya kemampuan siswa dalam berfikir spasial khususnya interpretasi visual foto udara dan simbolisasi peta.

Adapun tahapan pelaksanaan terdiri dari tiga hal yaitu 1) persiapan, 2) praktik terbimbing, dan 3) evaluasi. Pada tahap persiapan, tim PKM menyiapkan prosedur praktikum, modul praktikum, alat dan bahan praktikum, dan memastikan sasaran peserta baik jumlah maupun kehadiran. Pada tahap kedua yaitu praktik terbimbing dilakukan dengan 5 cara yaitu 1) Siswa disiapkan tempat/ruang yang nyaman lengkap dengan meja, kursi, dan perlengkapan praktik. 2) Siswa diberikan instruksi untuk menginterpretasikan secara visual foto udara yang berisi potret wilayah lingkungan sekitar SMAN 1 Pemulutan. 3) Siswa diberikan instruksi untuk melakukan simbolisasi objek pada foto udara dengan cara menjiplak foto udara dengan menggunakan kertas kalkir. 4) Siswa diberikan instruksi untuk membuat legenda untuk memperjelas informasi pada objek yang telah disimbolisasi tersebut. 5) Siswa diinstruksi untuk menjelaskan peta yang telah dibuat terkait nama objek, simbol objek, dan keterkaitan objek dengan objek lainnya. Pada tahap terakhir yaitu evaluasi, tim PKM mengumpulkan hasil lembar kerja siswa secara kolektif dan menyesuaikan dengan rubrik indikator kesesuaian lembar kerja siswa dengan penilaian evaluasi.

\section{HASIL DAN PEMBAHASAN}

Kegiatan pemanfaatan seni kartografi untuk meningkatkan kemampuan spasial siswa SMA Negeri 1 Pemulutan dilaksanakan pada hari Selasa tanggal 26 Maret 2019. Adapun siswa-siswa yang terlibat berjumlah 40 siswa dari kelas XII IPS. Kegiatan ini dipandu oleh dosen dengan dibantu mahasiswa Program Studi Pendidikan Geografi FKIP Universitas PGRI Palembang.

Minimnya kemampuan siswa dalam berfikir spasial dapat mempengaruhi hasil belajar siswa pada mata pelajaran geografi. Diperlukan suatu metode yang bersifat interaktif dan stimulan untuk menarik perhatian siswa yaitu dengan memanfaatkan metode praktikum. Praktikum adalah suatu cara yang digunakan untuk mengaplikasi ilmu dengan mempraktikkan secara langsung teori yang didapat di kelas. Pada kegiatan ini, siswa diajak untuk mempraktikan ilmu pemetaan untuk meningkatkan kemampuan spasial melalui seni kartografi.

1) Pada tahap awal, siswa diberikan pemahaman konsep seni kartografi dengan metode ceramah terbimbing. Selanjutnya siswa diberikan kesempatan untuk tanya jawab terkait konsep seni kartografi khususnya tema interpretasi foto udara dan simbolisasi peta. Beberapa pertanyaan terkait pengenalan objek yang terekam pada foto udara sulit untuk dikenali oleh siswa. Tentunya selain tingkat familiaritas suatu objek dan wawasan kelokalan cukup mempengaruhi siswa untuk mengenali objek yang terekam pada media foto udara tersebut. Selain itu, kecakapan siswa dalam 
menginterpretasikan objek ke dalam simbol sangat minim.

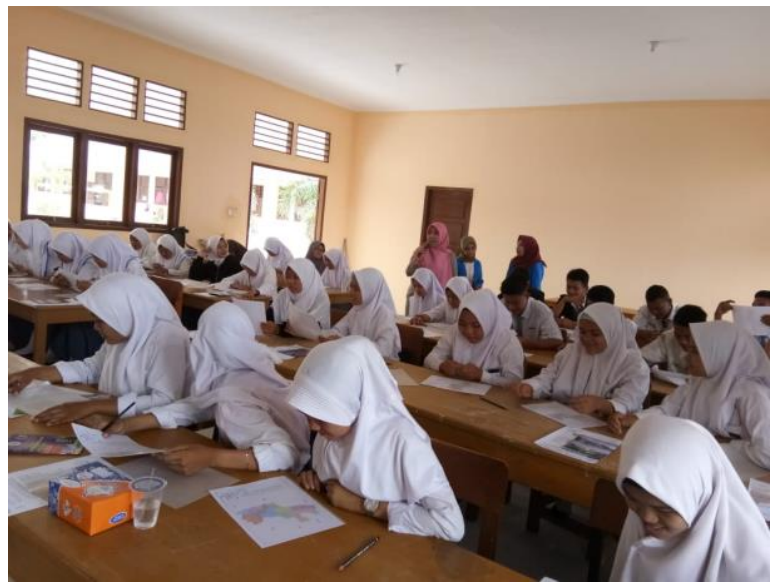

Gambar 1. Pemateri Memberi Penjelasan Tentang Konsep Seni Kartografi.

2) Pada tahap kedua, siswa diberikan pendampingan praktik terbimbing untuk mengeksplorasi foto udara melalui interpretasi visual. Foto udara yang digunakan adalah potret sebagaian wilayah SMA Negeri 1 Pemulutan dengan harapan siswa memiliki kecakapan spasial karena telah familiar dengan lingkungan sehari-hari. Selanjutnya, siswa menkonversi interpretasi visual yang telah dilakukan kedalam bentuk simbol sesuai kaidah kartografi pada bidang datar dengan memanfaatkan kertas kalkir dan alat tulis.

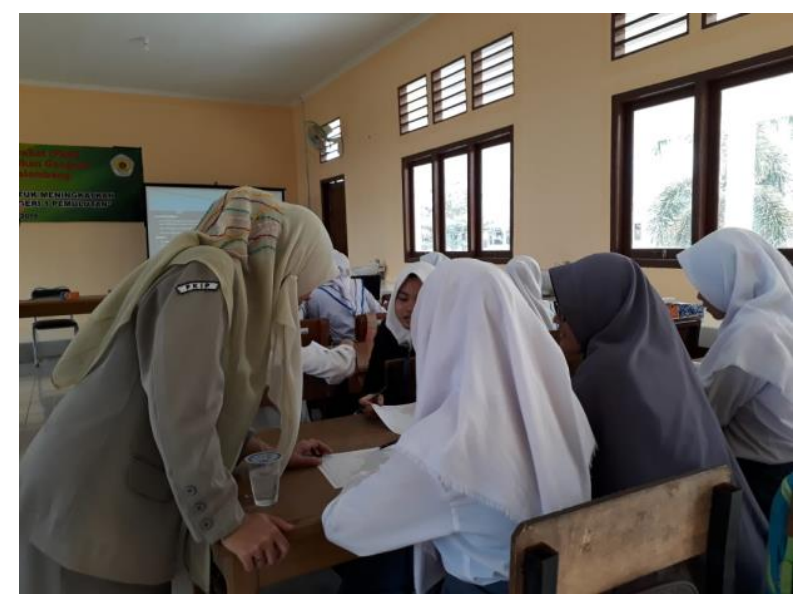

Gambar 2. Pendampingan Praktik Terbimbing.

Pada tahap akhir, siswa telah berhasil melakukan simbolisasi dengan kaidah kartografi. Selanjutnya siswa diminta untuk menjelaskan makna simbol yang telah di buat serta mengkaitkan simbol tersebut dengan pendekatan keruangan, seperti pemaknaan keterkaitan objek dengan objek lainnya. Setelah kegiatan praktik selesai tim membagikan angket yang berisi tentang persepsi siswa terhadap pelaksanaan kegiatan praktikum ini, pada butir pertama yang menanyakan apakah kegiatan serupa pernah mereka dapatkan, semua siswa menyatakan belum pernah mendapatkan pengalaman kegiatan pembelajaran praktik ini. Pada butir-butir selanjutnya ditanyakan tentang apakah kegiatan pembelajaran ini menarik minat siswa untuk belajar geografi, sebanyak $95 \%$ siswa menjawab tertarik dan ingin mengalami kembali pengalaman belajar serupa. Selain angket, siswa juga diberikan instrumen tes hasil belajar dengan materi simbolisasi peta, dan sebanyak $84 \%$ atau sebanyak 57 siswa mampu mencapai nilai ketuntasan minimum atau KKM yang telah ditentukan oleh sekolah yaitu 75 .

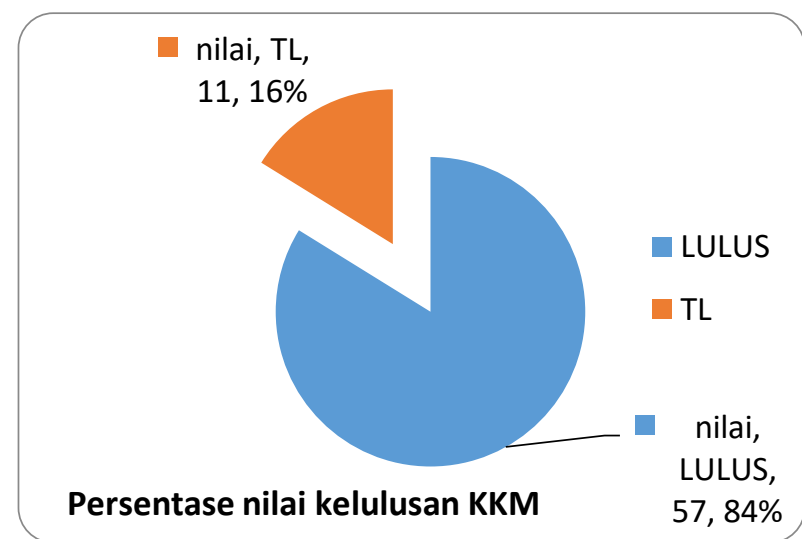

Gambar 3. Persentase Nilai Kelulusan KKM.

Adapun tujuan kegiatan pengabdian kepada masyarakat ini untuk meningkatkan kemampuan dan pemahaman spasial melalui pemanfaatan seni kartografi pada siswa di SMA Negeri 1 Pemulutan. Kajian dalam penmbelajaran geografi tidak hanya sekedar mempelajari fenomena geosfer dalam konteks lingkungan dan keruangn, namun juga bentuk, ukuran arah dan pola dari fenometa tersebut serta mengkaji keterkaitan atau hubungan antara fenomena-fenomena tersebut. Berdasarkan wawanca dengan salah satu guru geografi di SMA Negeri 1 Pemulutan, penulis mendapati data bahwa kemampuan berpikir spasial siswa masih dikategorikan rendah, data ini didasarkan pada capaian nilai ulangan harian siswa yang lulus nilai ketuntasan minimum sebesar 22\%. Dari 68 siswa yang teridri dari 2 kelas XII. Artinya hanya 15 orang yang mencapai nilai ketuntasan minimum, dengan rata-rata nilai adalah 52,94

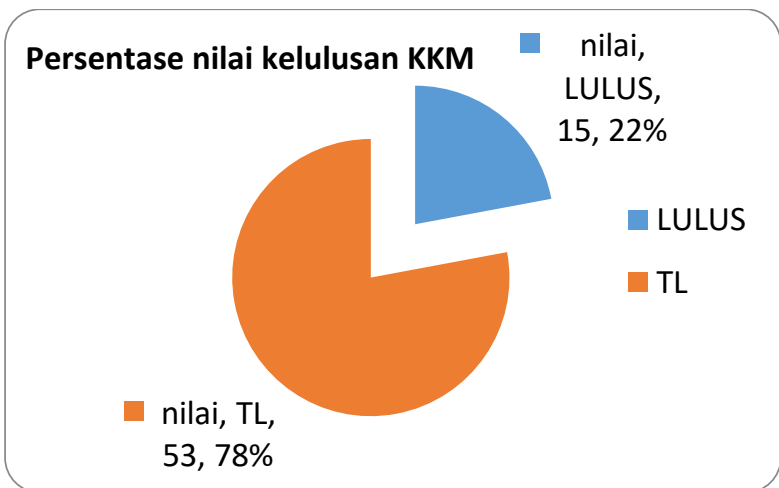

Gambar 4. Persentase Nilai Kelulusan KKM.

Melalui kegiatan PPM ini, diharapkan kemampuan berpikir spasial siswa SMA Negeri 1 Pemulutan ini dapat meningkatkan, dengan pemberian kegiatan 
pembelajaran berupa praktik kegiatan terbimbing dengan memanfaatkan foto udara sebagai media pembelajaran yang menyenangkan, melalui kegiatan praktik ini siswa diajak untuk menvisualisasikan dan mengintepretasi foto udara dan simbolisasi peta.

\section{KESIMPULAN}

Pelaksanaan kegiatan pengabdian pada masyarakat terdiri dari tiga tahapan pelaksanaan, yaitu tahap persiapan, pelaksanaan prektek terbimbing, dan evaluasi. Kegiatan ini diikuti dengan sangat baik oleh siswa sebagai peserta belajar. Berdasarkan evaluasi yang dilakukan di akhir kegiatan praktik, kegiatan ini dinilai menarik minat siswa sebesar 95\%. Siswa mengakui bahwa baru pertama kali mendapatkan materi praktik pembuatan peta dengan bantuan visual foto udara. Hasilnya siswa dapat lebih mudah memahami tentang simbolisasi pada peta terlebih karena siswa langsung membandingkan foto udara wilayah lingkungan sekitar SMA Negeri 1 Pemulutan yang merupakan wilayah yang sangat mereka kenali. Seluruh kegiatan telah terlaksana dengan baik, hal ini karena adanya dukungan dari pihak SMA Negeri 1 Pemulutan dan Universitas PGRI Palembang.

\section{UCAPAN TERIMA KASIH}

Terima kasih disampaikan kepada LPPKM Universitas PGRI Palembang yang telah mendanai keberlangsungan jurnal ini dan seluruh guru dan murid-murid dari SMA N 1 Pemulutan yang sudah bersedia memberikan kesempatan kepada tim pengabdian Kepada Masyarakat untuk berbagi ilmu kepada siswa kelas XII IPS.

\section{DAFTAR PUSTAKA}

Handoyo, S. (2009). Kaidah Kartografis; Sebuah kontemplasi Profesi. Jakarta. Forum Teknik Atlas Badan Informasi Geospasial.

Imamuddin, M. dan Isnaniah. (2018). Profil Kemampuan Spasial Mahasiswa Camper dalam Merekonstruksi Irisan Prisma Ditinjau Dari Perbedaan Gender. MaPan : Jurnal Matematika dan Pembelajaran. Volume 6, No 1, June 2018 (31-39).

DOI: https://doi.org/10.24252/mapan.2018v6n1a4

Mohan, A. L. M. (2013). Spatial Thinking About Maps Development of Concepts and Skills Across the Early Years. In National Geographic Education Programs. Retrieved from https://media.nationalgeographic.org/assets/file/ SpatialThinkingK-5FullReport.pdf

Setiawan, I. (2016). Peran Sistem Informasi Geografis (Sig) Dalam Meningkatkan Kemampuan Berpikir Spasial (Spatial Thinking). Jurnal Geografi Gea, 15(1), 83-89. https://doi.org/10.17509/gea.v15i1.4187

Setyawati, D. (2013). Pemetaan Lokasi dan Sebaran Hotel Serta Jangkauannya Terhadap Obyek Wisata di Kota Yogyakarta. Skripsi. Universitas Gadjah Mada.

Susetyo, D. B., Hakim, Y. F., Arimjaya, I. W. K., \& Ainiyah, R. (2014). Aspek Kartografi Peta Joint
Border Mapping (JBM) Republik IndonesiaMalaysia. GEOMATIKA, 20(1). 